\title{
Multivariate Analysis on the Effectiveness of Monetary and Fiscal Policies in Fiji
}

\author{
JAUHARI DAHALAN \\ Faculty of Economics, \\ Universiti Utara Malaysia \\ T.K. JAYARAMAN \\ Economics Department \\ University of the South Pacific
}

(1)

By utilising a Cointegrating Vector Autoregressive Model, this paper assesses the relative effectiveness the fiscal and monetary policies on growth. It is observed that government expenditure has the strongest - effect on Fiji's national income which significantly explains Fiji's GDP error variance even after a three year period with regard to the effect of shocks, we observed that the national income impulse respons to the one standard error shock among all macroeconomic variables, i.e. government expenditure and foreign assets, which is not permanent but transitory.

Keywords: Vector autoregressive; Co-integration; Variance decomposition; Impulse response function.

\section{ABSTRAK}

Artikel ini menilai keberkesanan relatif polisi fiskal dan monetari ke atas pertumbuhan ekonomi negara Fiji dengan menggunakan kaedah Model Vektor Kointegrasi Otoregresif. Hasil yang diperoleh menunjukkan perbelanjaan kerajaan atau negara memberi kesan yang signifikan kepada pendapatan negara Fiji. Ini dapat dikaitkan dengan ralat varian KDNK yang signifikan bagi Fiji walaupun selepas - tempoh tiga tahun. Hasil kajian juga memperlihatkan pendapatan negara 'impulse response' bersifat transitory kepada gegaran satu sisihan ralat dalam pemboleh ubah makro: pembelanjaan negara, dan aset asing.

\section{INTRODUCTION}

Soon after their political independence in the second half of the last century, some of the Pacific Island Countries (PICs) preferred to pursue monetary independence by introducing national currencies of their own, while others continued using the currencies of their former colonial masters as legal tender. Those PICs, which set up their own monetary authorities for issuing independent currencies and for regulating and controlling money supply, found that monetary policy could also be used along with fiscal policy to promote economic growth and development. Furthermore, the newly acquired monetary independence enabled them to manipulate their exchange rates either to insulate their economies from imported inflation or to enhance the 
competitiveness of their limited range of exports, including copra and fish in the case of all PICs and sugar in the case of Fiji, and tourism, which is the main stay of all.

With the introduction of public sector reforms and deregulation of the PICs' economies in the 1990s, the concept of the central bank independence gained respectability and assumed more importance. Simultaneously, the use of direct instruments of monetary policy was replaced by market based, indirect instruments. These indirect instruments include central bank issued short-term papers, aimed at influencing short-term interest rates, as a key indicator signaling monetary stance of the country. The PICs, which have currencies of their own, have now accumulated two decades of experience in the pursuit of independent monetary policies and implementation. The objective of this paper is to assess the relative effectiveness monetary and fiscal policies. Since the span of data for all PICs is not long enough to make reliable inferences, only Fiji has been chosen as the country for study. The rest of the paper is organised as follows. The second section gives a brief economic background of the five major PICs, namely Fiji, Samoa, the Solomon Islands, Tonga and Vanuatu and their experiences in implementation of monetary and fiscal policies; the third section outlines the methodology adopted for the study and reports the results. The fourth section is a summary listing some recommendations for policy implications.

\section{BACKGROUND}

The PICs considerably vary in population and land area (Table 1). The challenges, however, faced by all the PICs are the same: limited skilled human resources, remoteness from major markets, small range of export commodities, heavy dependence on imports, and sluggish growth despite substantial external aid (Table 2).

\section{Table 1}

Pacific Islands - Selected Indicators

\begin{tabular}{|c|c|c|c|c|c|c|}
\hline - & Population & Per Capita & HD & & Aid & apita \\
\hline Region/Countries & 2003 & $\begin{array}{c}\text { (current } \\
\text { prices) } \\
\text { in USD } \\
2003 \\
\end{array}$ & $\begin{array}{l}\text { Rank } \\
2002\end{array}$ & $\begin{array}{c}\text { Capita } \\
\text { in USD } \\
2002\end{array}$ & $\begin{array}{l}\% \text { of } \\
\text { GDP } \\
1990\end{array}$ & $\begin{array}{l}\% \text { of } \\
\text { GDP } \\
2002\end{array}$ \\
\hline Cook Islands & 19 & 2,651 & 62 & 490.9 & - & 28.00 \\
\hline & 799 & 2,281 & 81 & 41 & - & 1.80 \\
\hline Fed Sates of Micronesia & 114 & 1,864 & 120 & 702 & - & 37.40 \\
\hline Kiribati & 85 & 530 & 129 & 203.3 & - & 18.60 \\
\hline Papua New Guinea & 5,099 & 523 & 133 & 36.4 & 12.80 & 7.20 \\
\hline $\begin{array}{l}\text { Republic of Marshall } \\
\text { Islands }\end{array}$ & 51 & 2,008 & 121 & 823.3 & - & 49.60 \\
\hline Samoa & 175 & 1,484 & 117 & 214.2 & 42.60 & 14.50 \\
\hline Solomon Islands & 418 & 541 & 124 & 56.8 & 21.70 & 11.00 \\
\hline Tonga & 98 & 1,347 & 63 & 217.2 & 26.30 & 16.40 \\
\hline Tuvalu & 11 & 345 & 118 & 454 & 472.7 & 45.00 \\
\hline Vanuatu & 183 & 1,138 & 129 & 133 & 33 & 11.70 \\
\hline
\end{tabular}

Source: ADB(2003), IMF(2003b), UNESCAP(2004) 
The PICs inherited their relatively large sized public sector from the colonial rulers. Since the private sector was weak, most of the economic activities were, until very recently, undertaken by the public sector. These activities at one time included commercial ventures including hotels and tourism related enterprises including duty free shops. The government was also the provider of jobs. As a result, the current budget is dominated by wages and salaries, sometimes with poor allocation for essential maintenance expenditure for current assets, such as physical infrastructure including roads, bridges, and public buildings. Very little was generated as operating budget surplus from current revenues towards contributing to capital budget, enabling the respective governments to spend on new incomecreating assets. The ratio of current expenditure to capital expenditure in PICs including Fiji has been around 80 to 20 .

Table 2

Macroeconomics Indicators

$\begin{array}{lcccc}\text { Regions/ } & \text { Exchange } & \text { Overall Fiscal } & \text { Inflation } & \text { Growth Rate } \\ \text { Countries } & \text { Rate } & \text { Balance } & (\%) & (\%) \\ & \text { Regime } & (\% \text { of GDP }) & & \end{array}$

\begin{tabular}{lccccccc}
\hline & & $1990-97$ & $1998-03$ & $1990-97$ & $1998-03$ & $1990-97$ & $1998-03$ \\
\hline Cook Islands & Dollarised & -0.4 & -1.4 & 2.7 & 3.5 & 3.0 & 3.5 \\
& Fixed Peg & -3.2 & -3.4 & 2.6 & 2.7 & 4.3 & 2.7 \\
$\begin{array}{l}\text { Fed Sates of } \\
\text { Micronesia }\end{array}$ & Dollarised & -15.9 & -7.8 & 2.3 & 0.2 & 3.3 & 0.2 \\
Kiribati & Dollarised & 6.8 & 4.2 & 3.0 & 5.0 & 4.2 & 5.0 \\
$\begin{array}{l}\text { Papua New } \\
\text { Guinea }\end{array}$ & Indep & -2.7 & -2.1 & 5.6 & -0.2 & 7.4 & -0.2 \\
$\begin{array}{l}\text { Republic of } \\
\text { Marshall Islands }\end{array}$ & Dollarised & -20.3 & 11.1 & -0.9 & -0.3 & 6.0 & 0.3 \\
Samoa & Fixed Peg & -2.8 & -0.6 & -3.1 & 3.9 & 5.7 & 3.9 \\
Solomon Islands & Fixed Peg & -5.1 & -3.6 & 2.9 & 3.7 & 10.8 & -3.7 \\
Tonga & Fixed Peg & 0.1 & -1.0 & 3.3 & 2.3 & 4.6 & 2.3 \\
Tuvalu & Dollarised & -6.1 & 18.0 & 5.6 & 4.8 & 2.9 & 4.8 \\
Vanuatu & Fixed Peg & -4.0 & -1.8 & 4.4 & 0.8 & 3.4 & 0.8 \\
\hline
\end{tabular}

Source: IMF(2003b), ADB(2003), UNESCAP(2004)

In the past, PICs were generally free from budgetary pressures. Generous external grants provided cushioning support, not only to current budget, but also financed capital expenditure to a substantial extent. From the late 1990s, annual budgetary support towards wages and salaries declined. Increasingly, aid became tied to specific programmes and projects, which were reflected in capital budgets. 
As external aid inflows were gradually declining and being monitored by donors with emphasis on their effectiveness, governments in PICs were turning to tap domestic resources. They found out they could successfully resort to public borrowing for financing their annual fiscal deficits. In small states with excess liquidity in the banking system, domestic borrowing was not difficult. In recent years, Fiji in particular, stepped up public borrowing to finance its deficits, the lender being the National Provident Fund, a public sector institution. The latter under law has been collecting monthly deductions from the salaries and wages of those employed in the public and private sectors and their employers at statutorily laid down rates. There has been another Justification as well. Investor confidence was very low soon after the 2000 coup and expectations that the private sector would recover soon did not materialise. As the country was going through a tough period, it was felt appropriate to boost investment by incurring fiscal deficits for a while. Fiji's fiscal deficits for the last four years appear to be part of countercyclical measures to compensate the loss of fall in private demand. In other PICs, notably in the Solomon
Islands and Vanuatu in the past, aside from public borrowing, the central banks were asked to pick up the unsold bonds when they were not fully subscribed. The monetisation of public debt by central banks was certainly a matter of concern as it led to rise in money supply giving rise to inflationary pressures. Whether public expenditure is undertaken purely as a countercyclical measure to meet the projected fall in demand or simply as - atpolitical commitment to step up growth through State sponsored schemes, the resultant fiscal expansion has been causing concern in one area: ise in public debt.

In some of the PICs, due to huge external grants, public debt level has been low. In Fiji, however, which receives grants only to the extent of $4 \%$ of GDP (the least in the region), public debt has been increasing, which is currently at $58 \%$ of GDP. The natural concern then is the growing annual interest burden, which the rising debt would impose on the government. Interest payments have to be made out of the primary balance, defined as surplus of current revenues over current expenditure, excluding interest payments. If countries failed to generate primary surpluses, the resulting effect would be further deterioration in their overall fiscal balances, leading to rise in debt levels, as interest payments have to be financed by recourse to additional public borrowing.

The role of monetary policy in small, open economies under a fixed exchange rate regime is limited. Furthermore, financial markets are also under developed with very few securities, dominated by government bonds and treasury bills. In addition, the players are very few: two to three foreign owned banks, a few government owned enterprises and the national provident funds (Asian Development Bank, 2001). Although interest rates in many small states have been freed from government controls and other restrictions, such as the government-directed lending for priority sectors have been discontinued, interest rates have not really come down. Since financial sectors are not yet fully developed, monetary policy has been found to be less effective, as the transmission mechanism has been found to be weak. Thus, most of the small economies have come to use fiscal policy as a tool for development. Economic growth of a country depends to a large extent on the nature and quality of economic policy (Collier \& Dollar, 2001). If there is a good environment for households and firms to save and invest in the developing world, the economic growth is generally observed. The International Monetary Fund (2003) claimed that where sound macroeconomic policies have been sustained, they have raised growth. Recent work by Loizidies and Vamvoukas (2005) examined the causal link between the relative size of government expenditure and economic growth and concluded that government expenditure fosters overall economic development. Government expenditure is regarded as an exogenous force that changes aggregate output. However, results from many studies are diverse (Landau, 1983; Ghali, 1998). Employing Pesaran bound test and non-causality test procedures, Huang and Chia (2006) demonstrated that there is no relationship between government expenditure and output in the case of Taiwan. Another factor considered as a main determinant of economic growth is export. 
Ramos (2001) claimed that there is a feedback effect between exports-output growth and importsoutput growth. As such, we included the export variable in our model.

Since our objective is to examine the efficacy of monetary and fiscal policies in terms of their impact on growth, our choice of variables included real gross domestic product (RGDP) and real government expenditure (RGE), both expressed in constant prices. The fiscal policy is represented by real government expenditure. As for monetary policy in a fixed exchanged rate regime, which is according to monetary approach to balance of payments, changes in money supply

- and a host of monetary variables such as in interest rate and bank credit would be reflected in net foreign assets. Like any other countries in the region, Fiji has a fixed exchange rate regime linked to a basket of currencies of major trading partners, thus changes in monetary policy lead - to changes in net foreign assets. Hence, real net foreign assets (RNFA), is chosen to represent the monetary policy variable. Fiji, like all other PICs and small island countries in other regions, is an open economy, with high dependence on export earnings. Periods of expansion and contraction in the rest of the world results in fluctuations

- in the demand for goods and services of small, open island economies and in the prices of what they export (Deere 1990). Real exports (REXP), is included in the analysis to represent foreign trade, which is vital for a small economy to overcome hurdles to realise economies of scale in production. To investigate the linkage between the economic growth and fundamental macroeconomic variables, we used annual data from 1970 to 2002 consisting of 33 years observations, which is reasonably adequate for a meaningful econometric analysis. All variables are transformed into log form.

The methodology employed by different empirical studies (Bynoe 1994; Osmond 1992; Chowdhury 1986; Darrat 1984) varies from the standard St Louis single equation model to its modified version with exports included as a measure of openness. In this paper, we resorted to a modified St Louis cointegrating four-equation vector autoregressive system (VAR) in line with Jordan, Craigwell, and Carter
(2000), which enabled estimation of the long-run relationships, which are theory consistent with a clear economic interpretation. Furthermore, the short-run dynamics are fully estimated within the VAR framework. The dynamic properties of the system are thereafter evaluated through persistence profiles and generalised impulse response functions.

\section{ECONOMETRIC METHODOLOGY}

\section{Unit Root Tests}

Before undertaking any econometric analysis, we examined the properties of individual time series in log levels in order to avoid any spurious regression results (Granger \& Newbold, 1974) by employing both Augmented Dickey-Fuller (ADF) and Phillips-Perron (PP) tests. The ADF tests developed by Dickey and Fuller (1979) and Said and Dickey (1984) are the most commonly used tests in empirical research. According to Schwert (1987), the Phillips-Perron test has poor size properties when the underlying data generating process has large negative movingaverage components. Nevertheless, Banerjee et al. (1993) concluded that the power of the ADF test would be higher for processes involving AR errors because the test regression captures AR terms precisely. We opted for the two test procedures as matter of comparing the results. The test is applied in higher-order models and models where the error terms are serially correlated. The $\mathrm{ADF}$ tests are based on the following regression models:

$$
\Delta Y_{t}=\alpha+\beta Y_{t-1}+\sum_{i=1}^{k} \gamma_{i} \Delta Y_{t-i}+\varepsilon_{t}
$$

and

$$
\Delta Y_{t}=\alpha+\mu t+\beta Y_{t-1}+\sum_{i=1}^{k} \gamma_{i} \Delta Y_{t-i}+\varepsilon_{t}
$$

where $Y_{t}$ is the series being tested, $\alpha$ is a constant, $\mathrm{t}$ represents a time and $\mathrm{k}$ is the lag truncation parameter. The first equation is the model without trend and the second equation represents the model with trend. The tests are pseudo $t-$ statistics for the null hypothesis of unit root $(\beta=$ $0)$. Alternatively, the PP tests are based on 
$Y_{t}=\mu+\alpha^{*} Y_{t-1}+\varepsilon_{t}$

$Y_{t}=\mu+\beta(t-T / 2) t+\alpha Y_{t-1}+\varepsilon_{t}$

where $Y_{t}$ represents the tested series as indicated in the ADF test, $\mathrm{T}$ is the number of observations, $\mu$, and $\mu^{\sim}$ are the non-zero means and $\beta$ is the linear trend term. In Equation (3), the null hypothesis $\left(\mathrm{H}_{0}: \alpha^{*}=1\right)$ is tested by using the and test statistics and $H_{0}:\left(\mu, \alpha^{*}\right)=(0,1)$ is testing using $Z\left(\Phi_{1}\right)$ test statistic. In Equation (4), the null hypothesis $\left(H_{0}: \alpha=1\right)$ is tested by the test statistics $Z(\alpha)$ and $Z\left(t_{\alpha}\right)$, and $H_{0}:(\beta, \alpha)=(0,1)$ by using test statistics $Z\left(\Phi_{3}\right)$ and $H_{0}:(\beta, \mu, \alpha)=(0,0,1)$ by using test statistics $Z\left(\Phi_{2}\right)$.

\section{(2)

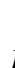

Bor investigating the linear relationship between macroeconomic variables (Engle \& Granger, 1987; Johansen \& Juselius, 1990; Johansen, 2000), a cointegration test is performed. The procedure adopted was the Johansen and Juselius (1990) and Johansen (2000) method, which was designed to examine the restrictions imposed by cointegration on the unrestricted Vector autoregression (VAR) model. The VAR model is estimated with maximum likelihood framework and has the advantage of allowing the joint determination of RGDP, RGE, RNFA, and REXP. Moreover, as noted earlier, it takes into account the short-run dynamics of the variables, while permitting the system of variables to return to their long-run steady-state equilibrium level.

The variables to be tested can be written as the following 4-dimensional VAR model:

-

$$
Z_{t}=\Gamma_{0}+\sum_{i=1}^{k} \Gamma_{i} Z_{t-i}+u_{t}
$$

where $Z_{t}=$ [RGDP, RGE, RNFA, REXP] is $(4 \mathrm{x} 1)$ vector of $\mathrm{I}(1)$ variables, $\Gamma_{1}$ is $(4 \times 4)$ matrix of parameters and $\Gamma_{0}$ is $(4 \times 1)$ vectors of constant term. $\mu_{t}$ is the $(4 \times 1)$ vector of random error term is white noise, which may be contemporaneously correlated, and $\mathrm{k}$ is the lag length. We rewrite equation (5) into error correction model (ECM) as follows:

$$
\Delta Z_{t}=\Gamma_{0}+\Gamma_{1} \Delta Z_{t-1}+\ldots+\Gamma_{k-1} \Delta Z_{t-k+1}+\Pi Z_{t-k}+u_{t}
$$

where $\Delta Z_{t}$ is the vector of changes in period $t$ and:

$\Gamma_{i}=-I+\sum_{i=1}^{k-1} \Gamma_{i}, \quad i=1,2, \ldots k$

$$
\Pi=-I+\sum_{i=1}^{k} \Gamma_{i}, \quad i=1,2, \ldots, k
$$

where $\Gamma_{i}$ is the short-run dynamics and $I$ is a (5x5) identity matrix. $\Pi$ is the long-run matrix which contains information about the long-run relationships between variables, and the rank $r$ determines the number of cointegrating vectors of $Z_{t}$. For $0<r<n$, there exists $r$ cointegrating vectors. In that case, $\Pi$ can be factorised as $\alpha \beta^{\prime}$, where both $\alpha$ and $\beta$ are $n \times r$ matrices. This model reflects a dynamic equilibrium relation, in which the expression $\beta Z_{t-1}$ represents the extent the system is deviated from the long-run export equilibrium relationship.

In estimating the long-run relationship between a set of variables, both maximum eigenvalue and trace test statistics are applied. The level of significance chosen is at 5\% level. The trace test is a likelihood ratio test for maximum $r$ cointegrating vectors against the alternative equals to $n$. The maximum eigenvalue test has an identical null hypothesis as trace test, with its alternative hypothesis of $(r+1)$ cointegrating vectors. Both tests have a non-standard asymptotic distribution and the critical values for the rank tests are tabulated in Johansen and Juselius (1990) and Osterwald-Lenum (1992).

\section{Error Correction Model (VECM) and}

\section{Granger-Causality Test}

Engle and Granger (1987) demonstrated that once variables are found to be cointegrated, there always exists a corresponding error-correction representation in which the short-run dynamics of the variables in the system are influenced by the deviation from equilibrium. Accordingly, it is implied that changes in the dependent variables are a function of the level of disequilibrium in the cointegrated relationship (captured by the error-correction term), as well as changes in other explanatory variable(s). 
Given that economic growth of Fiji and selected macroeconomic variables are cointegrated, the Granger representation theorem suggests that the dynamic relation between these variables should be examined within the framework of vector error correction model (VECM), and the system of the short-run dynamic of the economic growth series of Fiji is

$$
\begin{aligned}
& \Delta R G D P_{t}=\mu+\gamma E C T_{t-1}+\sum_{i=1}^{K 1} \delta_{i} \Delta R G E_{t-i}+\sum_{i=1}^{K 2} \tau_{i} \Delta R N F A_{t-i} \\
& \sum_{i=1}^{K 3} \xi_{i} \Delta R E X P_{t-i}+\sum_{i=1}^{K 4} \rho_{i} \Delta R G D P_{t-i}+\varepsilon_{t}
\end{aligned}
$$

where $E C T_{t-1}$ is the error correction term obtained - from the cointegration equation, $\gamma, \delta, \tau, \xi$, and $\rho$ are estimated parameters, and $\varepsilon_{t}$ is stationary random processes with zero mean and constant variance.

The VECM is useful for detecting the direction of Granger-causality when the variables - are cointegrated. Either the statistical significance of the t-test(s) of the lagged error-correction term(s) and/or the F-tests applied to the joint significance of coefficients of the lags of each explanatory variable, present evidence of Granger-causality. Moreover, the VECM can indicate econometric exogeneity of the dependent variables if both the - $\mathrm{t}$-test(s) and the F-tests are significant.

\section{Innovation Accounting Analysis}

The analysis of dynamic interaction in the post sample period was investigated through the innovation analysis, that is, impulse response functions (IRFs) and variance decomposition (VDC). An impulse response function traces out - the effect of an exogenous shock in one variable on the other variables in the system, while the variance decomposition analysis decomposes the forecast error variance for a certain variable into components accounted for by innovations of all variables in the system.

The estimated VECM in Equation (7) is transformed into an infinite order vector moving average (VMA) model:

$$
\Delta Z_{t}=\mu+\sum_{i=0}^{\infty} \Phi_{i} \varepsilon_{t-i}
$$

where $\Phi$ is a (4x4) matrix coefficient of impulse response functions which can be used to generate the effect of $\varepsilon_{\mathrm{t}-\mathrm{i}}$ on the entire time path I of the $\Delta \mathrm{Z}_{\mathrm{t}}$ sequences.

The variance decomposition can be obtained by computing the percentage of the i-th period ahead squared forecast error of one variable as produced by a one-standard deviation shock by the same or other variables. This enables us to identify forecast error attributed to different sources (its own innovation and innovations by other variables), and thus gives quantitative strength to the Granger causality between variables.

\section{EMPIRICAL RESULTS}

\section{Long-Run Relationship}

Prior to the cointegration test, each variable was checked for stationarity. The augmented DickeyFuller (ADF) and Phillips and Perron (PP) unit root tests were performed. The ADF and PP tests were based on a standard regression with a constant, and with a constant and time trend. The results from Table 3 indicate that each series is nonstationary in log levels and stationary in log first difference, suggesting that all variables are individually integrated of order 1, I(1).

Next, the cointegration analysis was performed to test for the presence of the long-run equilibrium among the four variables. Detailed results of the Johansen maximum likelihood estimation are reported in Table 4 . Both $\lambda$-max and $\lambda$-trace test statistics were used to determine the number of cointegration vectors. We observed that one cointegration vector is identified by $\lambda$ trace statistics while $\lambda$-max statistics identifies no cointegrating vectors using the $5 \%$ signicance level from Osterwald-Lenum (1992). In particular, the $\lambda$-max statistics tends to suggest a smaller number of cointegration vector than the $\lambda$-trace statistics. However, since the $\lambda$-trace statistics takes into account all (n-r) of the smallest eigenvalue, it tends to have more power than the $\lambda$-max statistics where the eigenvalue are evenly distributed (Kasa, 1992; Serletis \& King, 1997).

According to Cheung and Lai (1993), the $\lambda$-trace statistics is more robust than $\lambda$-max statistics. Moreover, Johansen and Juselius (1990) 
emphasised the use of the $\lambda$-trace statistics in cases where a conflict between these two test statistics occurs. Accordingly, we concluded that, at $5 \%$ level of significance, the economy growth of Fiji and the macroeconomic variables, i.e. the real government expenditure (RGE), real net foreign assets (RNFA) and real net exports (REXP), are bound together in the long-run by one cointegrationg vector. Residuals from the systems were tested for serial correlation. The Ljung-Box and Langrange Multiplier tests indicated the absence of serial correlation among residuals

Table 3

Unit Root Test Log Level and Log First Difference

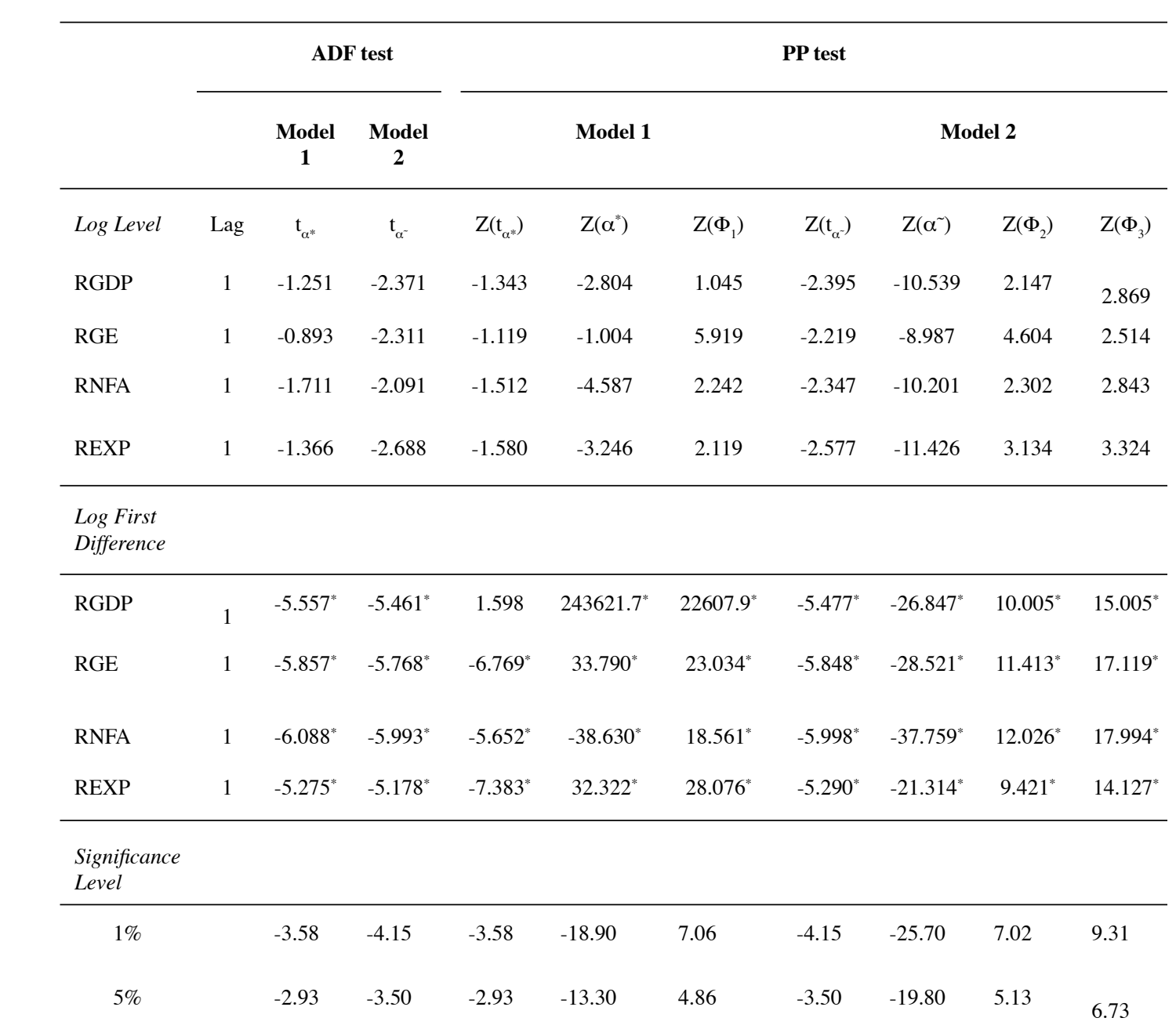

Note: $* / * *$ Significant at $1 \%$, and $5 \%$ respectively.

The optimal lag length for each of autoregressive process of ADF test is determined by Schwarz Bayesian Criterion (SBC).

The lag length in the PP tests were determined by Schwert (1987) formula: $l_{33}=\operatorname{Int}\left\{4(33 / 100)^{1 / 2}\right.$ to be three.

The adjusted $Z$ test statistics are given in detail in Perron (1988, pp. 308-309).

The Critical Value of $\mathrm{Z}\left(\alpha^{*}\right), \mathrm{Z}(\alpha \sim), \mathrm{Z}\left(\mathrm{t}_{\alpha_{*}}\right)$, and $\mathrm{Z}\left(\mathrm{t}_{\alpha}\right)$ are given in Fuller (1976, pp. 371 - 373).

The Critical Value of $Z\left(\Phi_{1}\right), Z\left(\Phi_{2}\right)$, and $Z\left(\Phi_{3}\right)$ are given in Dickey and Fuller (1981, pp. 1063). 


\section{Table 4}

Johansen Maximum Likelihood Test of the Cointegration Rank

\section{Lag length: 1}

Deterministic series: constant restricted to cointegration space

Hypotheses

\begin{tabular}{|c|c|c|c|c|c|c|c|c|}
\hline $\begin{array}{c}\mathrm{H}_{0}: \\
\mathrm{r}\end{array}$ & $\mathrm{H}_{1}: \mathrm{n}-\mathrm{r}$ & Eigenvalues: & $\begin{array}{l}\lambda_{\max } \\
\text { test }\end{array}$ & trace test & $\begin{array}{c}\lambda_{\max } \\
(0.95)\end{array}$ & $\begin{array}{c}\lambda_{\text {trace }} \\
(0.95)\end{array}$ & $\begin{array}{c}\lambda_{\max } \\
(0.90)\end{array}$ & $\begin{array}{c}\lambda_{\text {trace }} \\
(0.90)\end{array}$ \\
\hline 0 & 4 & 0.5385 & 24.74 & $53.49^{* *}$ & 28.14 & 53.12 & 25.56 & 49.65 \\
\hline 1 & 3 & 0.3689 & 14.73 & 28.75 & 22.00 & 34.91 & 19.77 & 32.00 \\
\hline 2 & 2 & 0.2469 & 9.07 & 14.02 & 15.67 & 19.96 & 13.75 & 17.85 \\
\hline 3 & 1 & 0.1432 & 4.95 & 4.95 & 9.24 & 9.24 & 7.52 & 7.52 \\
\hline
\end{tabular}

Residual Analysis: Autocorrelation

$\begin{array}{lrrrr} & \text { L-B (8) } & & \text { LM(1) } & \text { LM(4) } \\ \chi_{(112)}^{2} & 122.199 & \chi_{(16)}^{2} & 11.877 & 22.359 \\ \text { p-val } & 0.24 & \text { p-val } & 0.75 & 0.13\end{array}$

Table 5

Normalised Cointegrating Vectors, Test of Exclusion, and Residual Analysis

The First Normalised Eigenvectors

LRGDP $=-3.451+1.953$ LRGE -1.407 LRNFA + 0.925LREXP

Test of Exclusion of Each Variable

\begin{tabular}{|c|c|c|c|c|}
\hline Variable: & LRGDP & LRGE & LRNFA & LREXP \\
\hline$\chi_{(1)}^{2}$ & $5.79^{* *}$ & $7.57^{*}$ & $8.30^{*}$ & 0.87 \\
\hline \multicolumn{5}{|c|}{ Residual Analysis: Autocorrelation } \\
\hline \multicolumn{2}{|c|}{ LB (8) } & \multicolumn{2}{|c|}{$\mathrm{LM}(1)$} & $\mathrm{LM}(4)$ \\
\hline \multicolumn{2}{|c|}{$\chi_{(124)}^{2}: 118.01(0.63)$} & \multicolumn{2}{|c|}{$\chi_{(16)}^{2}: 5.235(0.99)$} & $\chi_{(16)}^{2}: 16.498(0.42)$ \\
\hline
\end{tabular}


Normalising the coefficient of economic growth, the restricted long-run relationships between the economic growth and macroeconomic variables for Fiji can expressed as follows:

$$
\begin{aligned}
L R G D P= & -3.451+1.953 L R G E-1.407 L R N F A+0.925 L R E X P(9) \\
& (1.238) \quad(3.032)
\end{aligned}
$$

The figures in the parentheses are the t-statistics. The result indicates that growth is positively related to government expenditure and exports. However, a negative long-run relationship was found between growth and real net foreign assets. Next, we tested the restrictions on each variable in the cointegration relation by using the GR test statistics given by Johansen (1991). The Iikelihood ratio tests are asymptotically chi-square with one degree of freedom. The results showed that all variables except for exports are statistically significant at 5\% level. This suggests that these variables in the cointegrating vector contribute to the long-run relationship. The adequacy of the cointegration model is checked by $\mathrm{LB}(8)$, LM(1) and LM(4) reported in Table 5. The results indicated that no autocorrelation in the residuals at the 5\% significance level.

a
Short-Run Relationship - Vector Error Correction Model (VECM) and GrangerCausality

Having established that the economic growth of Fiji is cointegrated with RGE, RNFA, and REXP, the interaction among these macroeconomic variables can be further examined. By estimating a VECM, we can examine the short-run impact of change in a given variable on the dependent variable. The VECM is based on a uniform lag length of one as in the cointegration model. By construction, the error-correction term represents the degree to which the economic growth is away from long-run alignment. The ECT is included in the above equation in order to guarantee that the economic growth does not drift too far apart. The short-run relationship of vector error correction model (VECM) is given as follows:

$\Delta \mathrm{LRGDP}=-0.394 E C T_{t-1}-10.674 \Delta L R G E_{t-1}+0.453 \Delta L R N F A_{t-1}$ $-0.0977 \Delta L R E X P_{t-1}+0.046 \Delta L R G D P_{t-1}$

The size of the coefficient on the error term $(-0.394)$ in the equation indicates that about $39 \%$ adjustment toward the long-run equilibrium takes place per year. Both F-tests and t-test(s) of

Table 6

Granger-Causality Tests Based on Vector Error Correction Model (VECM)

\section{F-statistics}

t-statistics

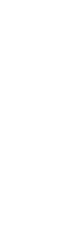

Dependent

variable

$\triangle$ LRGDP

$\triangle \mathrm{LRGE}$

$\triangle \mathrm{LRNFA}$

$\triangle$ LREXP

$\mathrm{ECT}_{\mathrm{t}-1}$

$4.187^{* *}$

0.340

0.138

$-3.417^{*}$

0.401

0.468

0.507

$-0.434$

$\triangle \mathrm{LRNFA}$

0.431

0.001

0.033

0.831

$\triangle$ LREXP

0.004

0.963

0.007

$-0.134$

Note: All variables except for the lagged error-correction terms $\left(\mathrm{ECT}_{\mathrm{t}-1}\right)$ are the first differenced denoted by $\Delta$.

The asterisk, ${ }^{*},{ }^{* *}$, indicate significance at $1 \%$ and $5 \%$ level, respectively. 
the VECM are reported in Table 6. In this system, the $t$-value of the coefficient of the ECT in RGDP is statistically significant at $1 \%$ level. The results confirm that all the variables are tied together with a long-run relationship and the error disequilibrium can be used to predict the next period of economic growth for Fiji. The statistical significance of either the F-tests of joint explanatory variables or the t-test of the ECT indicated the presence of Granger-causality. Hence, the monetary policy, fiscal policy, and exports directly affect economic growth for Fiji, as shown in Table 6. However, the economic growth for Fiji can be directly influenced by government expenditure - as evidenced by the statistical significance of the F-test at the 5\% level. This suggested that, if the whole system is considered for the direction of causality, the government expenditure will be (1)

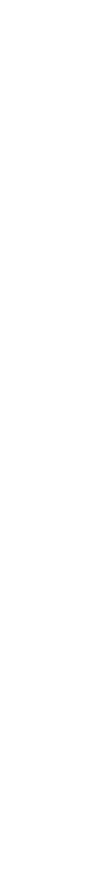
Table 7
Variance Decomposition

\section{Forecast Error Variance Decomposition}

The Granger-causality results from VECM give a qualitative analysis of the causal relations. However, the decomposition of variance gives a quantitative measure to these causal relations indicating how much the movement in one variable can explain the forecast error variance of another variable. Table 7 summarises the decomposition findings of 1-year, 2-year, 3year, 4-year and 5-year-ahead forecasts in each

\begin{tabular}{|c|c|c|c|c|c|}
\hline \multirow{2}{*}{$\begin{array}{l}\text { Variable } \\
\text { Explained }\end{array}$} & \multirow{2}{*}{$\begin{array}{l}\text { Forecast } \\
\text { Horizon }\end{array}$} & \multicolumn{4}{|c|}{ Percentage of Forecast Error Variance by One SD innovations in: } \\
\hline & & $\Delta$ LRGDP & $\Delta$ LRGE & $\triangle$ LRNFA & $\triangle \mathrm{LREXP}$ \\
\hline \multirow[t]{5}{*}{$\Delta$ LRGDP } & 1 & 100.000 & 0.000 & 0.000 & 0.000 \\
\hline & 2 & 85.277 & 13.113 & 1.178 & 0.432 \\
\hline & 3 & 84.789 & 13.064 & 1.494 & 0.653 \\
\hline & 4 & 84.760 & 13.091 & 1.494 & 0.656 \\
\hline & 5 & 84.756 & 13.092 & 1.496 & 0.656 \\
\hline \multirow[t]{5}{*}{$\Delta \mathrm{LRGE}$} & 1 & 5.358 & 94.642 & 0.000 & 0.000 \\
\hline & 2 & 5.509 & 90.133 & 2.600 & 1.758 \\
\hline & 3 & 5.537 & 89.993 & 2.716 & 1.754 \\
\hline & 4 & 5.535 & 89.974 & 2.737 & 1.754 \\
\hline & 5 & 5.536 & 89.973 & 2.737 & 1.754 \\
\hline \multirow[t]{5}{*}{$\triangle$ LRNFA } & 1 & 0.045 & 10.043 & 89.526 & 0.000 \\
\hline & 2 & 0.876 & 10.284 & 88.726 & 0.114 \\
\hline & 3 & 0.892 & 10.272 & 88.702 & 0.134 \\
\hline & 4 & 0.899 & 10.269 & 88.691 & 0.141 \\
\hline & 5 & 0.899 & 10.270 & 88.690 & 0.141 \\
\hline \multirow[t]{5}{*}{$\triangle$ LREXP } & 1 & 14.870 & 0.310 & 1.377 & 83.442 \\
\hline & 2 & 14.311 & 4.157 & 1.325 & 80.207 \\
\hline & 3 & 14.303 & 4.164 & 1.416 & 80.117 \\
\hline & 4 & 14.304 & 4.168 & 1.419 & 80.110 \\
\hline & 5 & 14.304 & 4.168 & 1.419 & 80.109 \\
\hline
\end{tabular}


macroeconomic variable. Our discussion focuses on the 3-year-ahead forecast results. The result indicated that the Fiji economic growth is more self-dependent with $85 \%$ of its own variance explained by its own shock even after three years. The real government expenditure has the strongest effect on Fiji's economic growth; and interestingly, the impact tends to be consistent after three years at $13 \%$. This result also supports the finding from VECM that only government expenditure directly affects Fiji's growth in economy. Rather, innovations in government expenditure are the most explainable. The forecast error variance in others variables ranged from $4.2 \%$ for REXP to $13.1 \%$ for RGDP. This result implied that a RGE shock has the strongest impact on each macroeconomic variable for Fiji, particularly on economic growth.

\section{(1)}

\section{mpulse Response Functions}

The impulse response functions indicated the transitory or persistent dynamic response of a variable to a one standard error shock to another variable. An impulse response function (IRF) of a shock - equal to one estimated standard error - to a given equation in the cointegrating VAR model is shown in Figure 1 and 2. These figures represent impulse response functions indicating the impact of policy-related variables specified in the model on the economic growth. is known that the results of the impulse response functions depend on the ordering of the variables. Hence, the ordering of the variables is based on the correlations between the real GDP and individual macroeconomic variables: real government expenditure, real net foreign assets, and real exports. Nevertheless, the results based on different orderings show no significant differences. Our inferences are therefore based on the ordering of LRGDP, LRGE, LRNFA, and LREXP.

In Figure 1, we can see that the impact effect of a unit shock in real government expenditure (a fiscal policy shock), measured as one standard error, on the real GDP (RGDP) is positive. The response function increases during the first three years. By the third year, the effect rises to about $0.11 \%$ and subsequently it remains constant over the rest of the horizon. Nevertheless, the effect of the real government expenditure on real net foreign assets (RNFA) and real exports (REXP) is below $0 \%$. The effect on net foreign assets - a monetary policy variable - is relatively small and at constant level of $-0.05 \%$ over the given horizon. The effect on real exports is slightly below $0 \%$ with the response function in declining trend during the first two years and finally remains constant around $-0.02 \%$ over the rest of the horizon.

Figure 2 shows the effect of the real net foreign assets (a monetary policy shock). The impact on the impulse response function for the real export is positive. The effect rises to around $0.08 \%$ during the first two years and remains

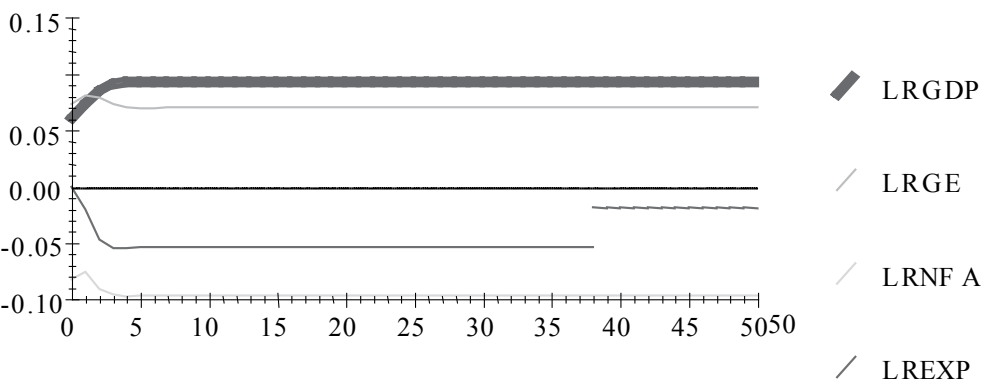

Horizon

Figure 1

Impulse response to one S.E shock for LRGE 
constant at this level throughout the remaining horizon. The impulse response function for the real government expenditure also rises, but it is significantly smaller as compared to the real export at around $0.01 \%$. However, the impact effect of the real net foreign assets on the real GDP is negative.
The effect declines to around $-0.12 \%$ by the third year and remains at this level over the remainder of the given horizon. In general, the impulse response functions appear to be consistent with the results obtained from Granger causality which is based on VECM and variance decompositions.

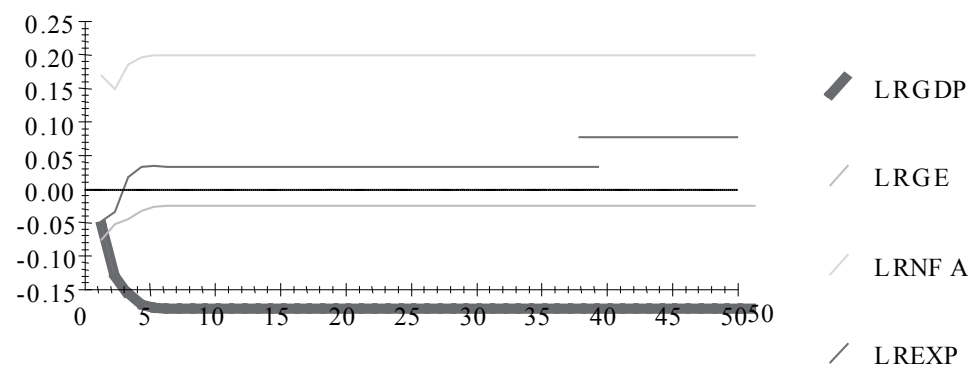

Horizon

Figure 2

Impulse responses to one S.E shock for LRNFA

\section{SUMMARY AND CONCLUSION}

Economic growth of Fiji in the last three - decades has raised questions regarding the Pelationship between growth in output and selected fundamental macroeconomic variables. In this paper, we investigated the effectiveness of monetary and fiscal policies for Fiji by examining the linkage between output and monetary and fiscal variables. The four fundamental variables were considered for short-run and long-run relationships and these included RGDP, RGE, RNFA, and REXP. Fiscal policy and monetary policy variables were represented by RGE and RNFA respectively. The short-run analysis of the VEC model included analyses such as Grangercausality, variance decomposition, and impulse response function. The empirical results indicated the existence of one cointegaration vector, signifying a long-term equilibrium relationship between economic growth and fundamental variables.

The Granger causality tests showed only the government expenditure directly affected growth in output for Fiji. There was no evidence of indirect causality or feedback relationship between other fundamental variables and Fiji's economic growth. The analysis of VDC and IRF suggested that Fiji's economic growth dynamically interacted with key fundamental variables. The RGE shock has the most powerful effect on Fiji's growth. Most variation in RGDP can be captured by innovation in RGE. The findings of our innovation accounting analysis provide additional support to the conclusion that RGDP is Granger caused by RGE. These results suggest that the fiscal variable has had a greater influence on growth as compared to other fundamental macroeconomic variables, particularly the monetary policy variable.

\section{END NOTES}

Corresponding author. The authors wish to thank the anonymous referees of this Journal for their helpful comments and suggestions. All remaining errors and deficiencies are the responsibility of the authors. 


\section{REFERENCES}

Asian Development Bank (ADB). (2003). Key indicators 2003. Manila: ADB.

ADB (2001). Financial sector development in pacific island economies. Manila: ADB.

Asian Development Bank (ADB). (1998a). Improving growth prospects in the Pacific. Manila: ADB.

Development Bank (ADB). (1998b). Reform in the Pacific: An assessment of $A D B$ 's assisatnce for reform programmes in the Pacific. Manila: ADB

Andersen, L. C. \& Jordan, J. L. (1968). Monetary C and fisacl actions: A test of their relative importance in economic stabilization. Federal Reserve Bank of St. Louis Review, 50 (10), 11-24.

Bynoe, A. (1994). Money and fiscal influences on economic activity in African countries. African Review of Money, Finance and Banking, 12 (1), 63-71.

Cheung, Y. W. \& Lai, K. S. (1993). Finite-sample sizes of Johansen's Likelihood Ratio Tests for cointegration. Oxford Bulletin of Economics and Statistics, 55, 313-328.

Chowdhury, A. (1986). Monetary policy, fiscal policy and aggregate economic activity: Some further evidence. Applied Economics, 20 (1), 63-71.

Jarrat, C. (1984). The dominant influence of fiscal action in the developing countries. Eastern Economic Journal, 10 (3), 271-284.

Deere, C. (1990). In the shadow of the caribbean sun. Denver, Colorado: Westview Press.

Dickey, D. \& Fuller, W. A. (1981). Likelihood ratio statistics for autoregressive time series with a unit root. Econometrica, 49 (4), 1057-1072.
Dickey, D. \& Fuller, W. A. (1979). Distribution of the estimators for autoregressive time series with a unit root. J. Am. Stat. Assoc., 74 (366), 1057-1072.

Engle, R. F. \& Granger, C. W. J. (1987). Cointegration and error correction: Representation, estimation and testin. Econometrica, 55, 251-276.

Fuller, W. A. (1976). Introduction to statistical time series. New York: John Wiley \& Sons.

Ghali, K. H. (1998). Government size and economic growth: Evidence from a multivariate cointegration analysis. Applied Economics, 31, 975-987.

Granger, C. W. J. \& Newbold, P. (1974). Spurious regressions in econometrics. Journal of Econometrics, 2, 111-120.

Huang, C. J. \& Chia, F. (2006). Testing wagner's law using bounds test and a new granger non-causality test: Evidence for Taiwan. Journal of American Academy of Business, 8 (2), 86-90.

International Monetary Fund (IMF). (2003). International Financial Statistics Yearbook 2003. Washington D.C: IMF.

Johansen, S. (1991). Estimation and hypothesis testing of cointegration vectors in gaussian vector autoregressive models. Econometrica, 59 (6), 1551-1580.

Johansen, S. (2000). Modelling of cointegration in the vector autoregressive model. Economic Modelling, 17, 359-373.

Johansen, S. \& Juselius, K. (1990). The full information maximum likelihood procedure for inference on cointegration with applications to the demand for money. Oxford Bulletin of Economics and Statistics, 52 (2), 169-211. 
Jordan, A., Craigwell, R. \& Carter, A. (2000). The potency of monetary and fiscal policies in caribbean countries: A cointegrating VAR approach. Savings and Development, 24 (3), 325-342.

Kasa, K. (1992). Common stochastic trends in international stock markets. Journal of Financial and Quantitative Analysis, 26 (3), 636-376.

Landau, D. (1983). Government expenditure and economic growth: A cross-section study. Southern Economic Journal, 49, 783-792.

Loizides, J. \& Vamvoukas, G. (2005). Government expenditure and economic growth: Evidence from trivariate causality testing. Journal of Applied Economics, 8 (1),125152.

Osmond, D. (1992). The potency of monetary and fiscal policies in sub-saharan countries: St. Louis Model Estimate. African Review of Money and Banking, 1 (1), 17-27.

Osterwald-Lenum, M. (1992). A note with quartiles as the asymptotic distribution of the Maximum Likelihood Cointegration Rank test statistics. Oxford Bulletin of
Economics and Statistics, 54 (3), 461472.

Osmond, D. (1992). The potency of monetary and fiscal policies in Sub-Saharan Countries: St. Louis Model Estimate. African Review of Money and Banking, 1 (1), 17-27.

Ramos, F. F. R. (2001). Exports, importd, and economic growth in Portugal: Evidence from causality and cointegration analysis. Economic Modelling, 18, 613-623.

Said, A. \& Dickey, D. A. (1984). Testing for unit roots in autoregressive-moving average models of unknown order. Biometrika, 71, 599-607.

Schwert, W. G. (1987). Effect of model specification on tests for unit roots in macroeconomic data. Journal of Monetary Economics, 20 (1), 73-103.

Serletis, A. \& King, M. (1997). Common stochastic tends and convergence of European Union stock markets. The Manchester School, 65 (1), 44-57.

United Nations Economic and Social Commission for Asia and the Pacific (UNESCAP) (2004). Economic and Social Survey 2004. Bangkok: UNESCAP. 